\title{
FORMULATION AND CHARACTERIZATION OF SILK FIBROIN FILMS AS A SCAFFOLD FOR ADIPOSE-DERIVED STEM CELLS IN SKIN TISSUE ENGINEERING
}

\author{
T. CHLAPANIDAS ${ }^{1}$, M.C. TOSCA ${ }^{1,2}$, S. FARAGÒ ${ }^{3}$, S. PERTEGHELLA ${ }^{1}$, M. GALUZZI $^{1,2}$, G. LUCCONI ${ }^{1}$, \\ B. ANTONIOLI ${ }^{2}$, F. CIANCIO ${ }^{4}$, V. RAPISARDA ${ }^{5}$, D. VIGO ${ }^{6}$, M. MARAZZI ${ }^{2}$ \\ AND M. FAUSTINI ${ }^{6}$, M.L. TORRE ${ }^{1}$
}

'Dipartimento di Scienze del Farmaco, Università degli Studi di Pavia, Pavia, Italy.

${ }^{2}$ Terapia Tissutale, Azienda Ospedaliera Ospedale Niguarda Ca' Granda, Milan, Italy.

${ }^{3}$ Innovhub, Divisione Stazione Sperimentale per la Seta, Milan, Italy.

${ }^{4}$ Istituto di Chirurgia Plastica, Università degli Studi di Firenze, Firenze, Italy.

${ }^{5}$ Chirurgia Plastica e Centro Grandi Ustionati, Azienda Ospedaliera Ospedale Niguarda Ca'Granda, Milan, Italy.

${ }^{6}$ Dipartimento di Scienze Veterinarie e Sanità Pubblica, Università degli Studi di Milano, Milan, Italy.

Skin substitutes are epidermal, dermal or complete bilayered constructs, composed by natural or synthetic scaffolds and by adherent cells such as fibroblasts, keratinocytes or mesenchymal stem cells. Silk fibroin is a promising polymer to realize scaffolds, since it is biocompatible, biodegradable, and exhibits excellent mechanical properties in terms of tensile strength. Moreover, fibroin can be added of others components in order to modify the biomaterial properties for the purpose. The aim of this work is to prepare silk fibroin films for adipose-derived stem cell (ADSCs) culture as a novel feeder layer for skin tissue engineering. Pectin has been added to promote the protein conformational transition and construct strength, while glycerol as plasticizer, providing biomaterial flexibility. Eighteen formulations were prepared by casting method using fibroin, pectin (range $1-10 \%$ w/w), and glycerol (range 0-20\% w/w); films were characterized by Fourier transform infrared spectroscopy and differential scanning calorimetry assay, to select the optimal composition. A stable fibroin conformation was obtained using $6 \% \mathrm{w} / \mathrm{w}$ pectin, and the best mechanical properties were obtained using $12 \% \mathrm{w} / \mathrm{w}$ glycerol. Films were sterilized, and human ADSCs were seeded and cultured for 15 days. Cells adhere to the support assuming a fibroblastic-like shape and reaching confluence. The ultrastructural analysis evidences typical active-cell features and adhesion structures that promote cell anchorage to the film, thus developing a multilayered cell structure. This construct could be advantageously employed in cutaneous wound healing or where the use of ADSCs scaffold is indicated either in human or veterinary field.

The development of skin substitutes dates back to 1975 , when Rheinwald and Green (1) cultured keratinocytes on a layer of lethally irradiated $3 \mathrm{~T} 3$ murine fibroblasts. Currently, this method remains the most reliable and widely used for in vitro keratinocyte culture, but some concerns are emerging about their safety (2-5). To overcome these limits, Sugiyama et al. (6) proposed the use of human irradiated adipose-derived stem cells (ADSCs) as a feeder cell layer: results showed that the morphology of irradiated stem cells was similar to 3T3, and both cell lines (stem and 3T3 cells) expressed genes promoting keratinocyte proliferation. Other researchers also showed that non-irradiated ADSCs can boost epithelialization, angiogenesis (7), capillary density and granulation thickness of transplanted cell-enriched collagen sponges (8). Altman et al. (9) observed that ADSCs, once seeded on acellular dermal matrix and applied on murine wound, spontaneously differentiated along vascular endothelial, fibroblastic and epidermal epithelial lineages and significantly improved wound healing; moreover, cells localize at implantation site.

Current cutaneous substitutes are epidermal, dermal or

Key words: Silk fibroin films, adipose-derived stem cells, bioengineered skin

Corrisponding author: Mario Marazzi

Struttura Semplice Terapia Tissutale

0394-6320 (2013)

Azienda Ospedaliera Ospedale Niguarda $\mathrm{Ca}^{\prime}$ Granda

Piazza Ospedale Maggiore 3,

20162 Milan, Italy.

tel. 0264444681

E-mail: mario.marazzi@ospedaleniguarda.it DISCLOSURE: ALL AUTHORS REPORT NO CONFLICTS OF INTEREST RELEVANT TO THIS ARTICLE. 
complete bilayered constructs seeded with keratinocytes, fibroblasts or both, respectively. Skin substitutes are composed by natural or synthetic scaffolds and must lead cells to tissue reconstruction. Commercial skin grafts are principally collagen-based matrices, such as hydrogels, sponges or lattices. Other natural materials (e.g. chitosan, fibrin and hyaluronan) are commercialized, but further clinical data are needed for FDA approval (10). A promising natural polymer is represented by silk fibroin, because of its peculiar biocompatibility (11), biodegradability (12), tensile strength and versatility (13). Besides textile industry, silk fibroin has been employed as suture material for centuries (14) and, more recently, in several biomedical fields as in hydrogels, membranes or scaffolds for regenerative medicine $(13,15-23)$.

The silk fibroin, usually extracted from the silkworm (Bombyx mori) cocoons, can assume three molecular conformations: Silk II ( $\beta$-sheet structure), stable and water-insoluble; Silk I (a mixture of random coil, $\alpha$-helix and $\beta$-turn), metastable and water-soluble; Silk III ( $\alpha$-helix structure at the water/air interface) (24, 25 ). The native silk fibroin is purified from sericin by the de-gumming process, and has a predominant Silk II structure. De-gummed fibers of silk fibroin can be used as they are or can be regenerated in order to obtain an aqueous fibroin solution. The regenerated fibroin is then processed in different ways to produce adequate scaffolds $(13,20,26-28)$. The regenerated silk fibroin, in aqueous solution or as scaffold, mainly presents Silk $I$ form. Since the Silk II conformation is a fundamental condition for the employ of silk fibroin in regenerative medicine, it is mandatory to promote the conformational transition from Silk I to Silk II by treating the Silk I form with organic solvents (such as methanol or ethanol) (2931 ), mechanical stress, temperature change or presence of other polymers, such as alginate, polyethylene glycole, chitosan, pectin $(24,32)$, and glycerol (33). The pectin, a natural polysaccharide polymer constituting the plant cell wall, has been recently employed for several biomedical applications, including drug and gene delivery, wound healing and tissue engineering; in particular, pectin hydrogels were used for bone tissue regeneration, as prosthetic nucleus pulposus substitutes or as wound healing patches (34). Glycerol is a plasticizer and has been added to fibroin by Lu et al. (33) to obtain insoluble and flexible films, improving their mechanical properties when compared with pure silk fibroin films:

The aim of this work is to prepare silk fibroin films for ADSCs culture as a novel feeder layer for skin tissue engineering. Pectin has been added to promote the protein conformational transition and construct strength, while glycerol as plasticizer, providing biomaterial flexibility.

\section{MATERIALS AND METHODS}

\section{Preparation and sterilization of silk fibroin films}

The fibroin solubilization was performed as reported by Chlapanidas et al. (35): briefly, cocoons of Bombyx mori were degummed in autoclave, dried at room temperature and treated with a solution of $\mathrm{Ca}\left(\mathrm{NO}_{3}\right)_{2}(75 \% \mathrm{w} / \mathrm{v})$ in methanol. After filtering under vacuum, the solution was dialyzed, and the final concentration of aqueous silk fibroin solution was $5 \% \mathrm{w} / \mathrm{v}$.

Pectin powder (Pectine Industrie, Italy) was solubilized in deionized water under stirring at $80^{\circ} \mathrm{C}$, while glycerol (Fluka, Germany) was diluted 1:1 in water; silk fibroin, pectin and glycerol were mixed under soft stirring, cast into molds $(8.5 \mathrm{~cm}$ diameter) to guarantee solvent evaporation $\left(60^{\circ} \mathrm{C}, 6\right.$ hours $)(32)$. Eighteen films were obtained using different fibroin-pectinglycerol ratios reported in Table 1: the first group of films (A-F films, Group 1, see Table 1) is composed by fibroin and pectin only, with a pectin concentration between 1 and $10 \% \mathrm{w} / \mathrm{w}$. In the second and the third group (G-N and O-T films, Group 2 and Group 3, respectively, see Table 1) glycerol is added at concentration $1-10 \%$ and $2-20 \% \mathrm{w} / \mathrm{w}$ respectively, and for each formulation the ratio pectin:glycerol is 1:1 (for Group 2) or 1:2 (for Group 3). Two film formulations were selected and sterilized by three methods: moist heat (autoclave, $121^{\circ} \mathrm{C}$ for 20 minutes), dry heat $\left(160^{\circ} \mathrm{C}\right.$ for 20 minutes) and gamma irradiation (at 20 and $60 \mathrm{kGy}$ ). A microbial test was performed after sterilization processes: films were incubated for 7 days in DMEM medium (Euroclone, Italy) at $37^{\circ} \mathrm{C}, 5 \% \mathrm{CO}_{2}$ : after this period, $5 \mathrm{~mL}$ of the supernatant were inserted into adequate flask and analyzed using BacT/ALERT 3D system to detect bacteria and fungi.

\section{Fourier Transform Infrared Spectroscopy and Differential Scanning Calorimetry analysis}

Before and after sterilization, films were analyzed by - Fourier Transform Infrared Spectroscopy (FTIR) on a Bruker Alpha-E spectrometer equipped with a MIRacle ${ }^{\mathrm{TM}}$ attenuated total reflection Diamond crystal cell in reflection mode. Background measurements were taken twice with an empty cell and subtracted from the sample readings. The FTIR spectra in the absorbance mode were obtained in the spectral regions of $500-3500 \mathrm{~cm}^{-1}$. Each spectrum of the samples was acquired by accumulation of 32 scans with a resolution of $4 \mathrm{~cm}^{-1}$.

Samples were also analyzed by Differential Scanning Calorimetry (DSC) using a Mettler TA30 differential calorimeter. Thermal scanning was carried out on $3 \mathrm{mg}$ of each sample under nitrogen atmosphere (temperature range: $10^{\circ} \mathrm{C}-500^{\circ} \mathrm{C}$, rate: $\left.10^{\circ} \mathrm{C} / \mathrm{min}\right)$

\section{Cell culture}

A sample of adipose tissue (about $50 \mathrm{~mL}$ ), collected from one informed subject, was suspended in phosphate buffered saline (PBS) (Euroclone) with penicillin/streptomycin 1\% (Euroclone), put into a sterile box, and forwarded to the laboratory at a temperature of $4^{\circ} \mathrm{C}$. Adipose tissue was digested as reported by Faustini et al. (36), using a collagenase concentration of $0.02 \%$ $\mathrm{w} / \mathrm{v}$ (Sigma, USA) for one hour; cells were then centrifuged and washed twice with PBS. Stromal vascular fraction was plated on plastic surface $\left(10.000 \mathrm{cell} / \mathrm{cm}^{2}\right)$ in DMEM/F12 (Euroclone), 
$10 \%$ fetal bovine serum (ThermoFisher, USA), $1 \%$ penicillin/ streptomycin and 1\% Amphotericin B (Euroclone); adherent stem cells were expanded till the 3 rd passage. Films were cut in $1 \mathrm{~cm}^{2}$-squares and cells were then cultured on the prepared films $\left(20,000\right.$ cells $/ \mathrm{cm}^{2}$ of film) for 15 days at $37^{\circ} \mathrm{C}, 5 \% \mathrm{CO}_{2}$.

\section{Characterization of cell culture}

After cell culture, silk fibroin cell seeded films were treated with $2 \%$ glutaraldehyde (Sigma) for $30 \mathrm{~min}$ at room temperature, then $2 \%$ glutaraldehyde and cacodylate buffer (Sigma) $0.1 \mathrm{M}$ for $30 \mathrm{~min}$ at $4^{\circ} \mathrm{C}$, and finally washed with cacodylate buffer $0.1 \mathrm{M}$. Samples were dehydrated using a graded ethanol series (from $30 \%$ to $100 \%$ ) (Carlo Erba, Italy), freeze-dried, critical point dried, sputter coated with gold and analyzed using a scanning electron microscope (JEOL JSM-6380LV) operating at low vacuum degree, $20 \mathrm{kV}$, retrodiffused electron signal.

Moreover, samples were first fixed with $2.5 \%$ glutaraldehyde in cacodylate buffer $0.1 \mathrm{M}$ ph 7.4 , then with osmium tetroxide (Sigma) $0.1 \%$ and finally dehydrated with alcohol scale. Films were included in Epon 812/Araldite resin (Sigma) before being sectioned using Ultracut $\mathrm{S}$ Ultramicrotome. The thin sections were treated with Toluidine Blue staining (Sigma) and observed under an optical microscope, while the ultrathin sections were observed for transmission electron microscopy with a JEOL JEM 1200 EX instrument.

\section{RESULTS}

The eighteen different films had different characteristics according to pectin and glycerol content. Films composed by fibroin and pectin only resulted rigid, fragile and they broke during mold removal; the presence of glycerol improved film elasticity and resistance. FTIR and DSC analysis were carried out to evaluate the fibroin

Table 1. Weight/weight percentage composition of silk fibroin flims and wavenumber of Amide I peak.

\begin{tabular}{|c|c|c|c|c|c|}
\hline & Film & Fibroin & Pectin & Glycerol & Amide I peak $\left(\mathrm{cm}^{-1}\right)$ \\
\hline \multirow{6}{*}{ 司 } & $\mathbf{A}$ & 99 & 1 & 0 & 1648.93 \\
\hline & B & 98 & 2 & 0 & 1648.53 \\
\hline & $\mathbf{C}$ & 96 & 4 & 0 & 1628.79 \\
\hline & D & 94 & 6 & 0 & 1625.51 \\
\hline & $\mathbf{E}$ & 92 & 8 & 0 & 1625.58 \\
\hline & $\mathbf{F}$ & 90 & 10 & 0 & 1625.83 \\
\hline \multirow{6}{*}{ 咨 } & $\mathbf{G}$ & 98 & 1 & 1 & 1647.99 \\
\hline & $\mathbf{H}$ & 96 & 2 & 2 & 1647.44 \\
\hline & I & 92 & 4 & 4 & 1630.68 \\
\hline & $\mathbf{L}$ & 88 & 6 & 6 & 1627.86 \\
\hline & $\mathbf{M}$ & 84 & 8 & 8 & 1627.33 \\
\hline & $\mathbf{N}$ & 80 & 10 & 10 & 1626.45 \\
\hline \multirow{6}{*}{ ڤ̆ } & $\mathbf{O}$ & 97 & 1 & 2 & 1648.00 \\
\hline & $\mathbf{P}$ & 94 & 2 & 4 & 1647.80 \\
\hline & $\mathbf{Q}$ & 88 & 4 & 8 & 1644.30 and 1627.00 \\
\hline & $\mathbf{R}$ & 82 & 6 & 12 & 1626.29 \\
\hline & $\mathbf{S}$ & 76 & 8 & 16 & 1626.02 \\
\hline & $T$ & 70 & 10 & 20 & 1625.69 \\
\hline
\end{tabular}

molecular conformation. Considering the Amide I peak obtained from FTIR spectra, a wavenumber of $\sim 1650$ $\mathrm{cm}^{-1}$ was related to Silk $I I$, while a wavenumber of $\sim 1625$ cm- 1 corresponded to Silk $I$ form. Among A-F groups, A and B films presented the Silk I conformation (Table 1); increasing pectin concentration, the Amide I peak shifted to lower frequencies and then remained unchanged in the case of films containing $6 \%, 8 \%$ and $10 \%$ pectin (D-F films, respectively) (Table 1 ).

These results indicated that the fibroin conformational transition was obtained using $6 \%$ of pectin, and the same behavior was observed for the second and third group of films (Table 1). The FTIR spectrum of $Q$ film (4\% pectin) presented the characteristic absorption bands of both

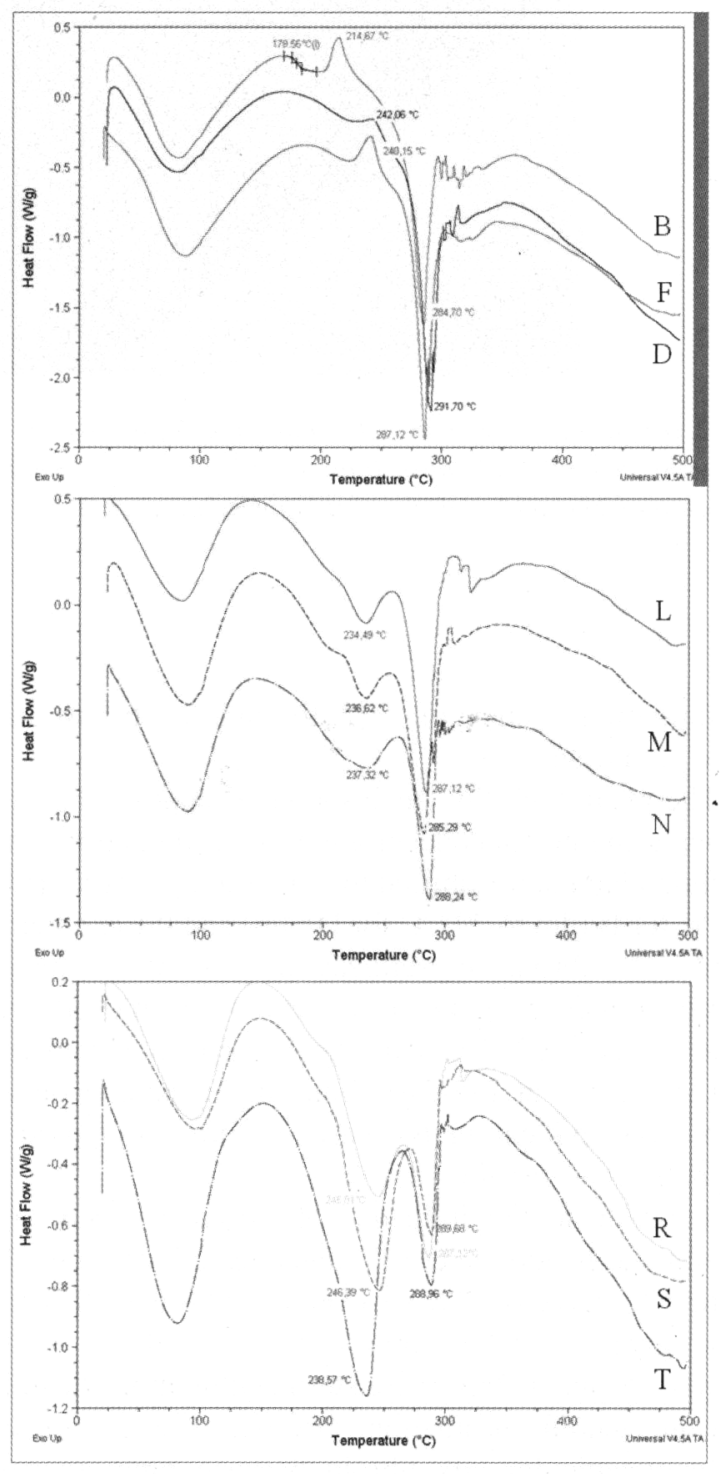

Fig. 1. Differential scanning calorimetry (DSC) patterns of different representative silk fibroin films. 


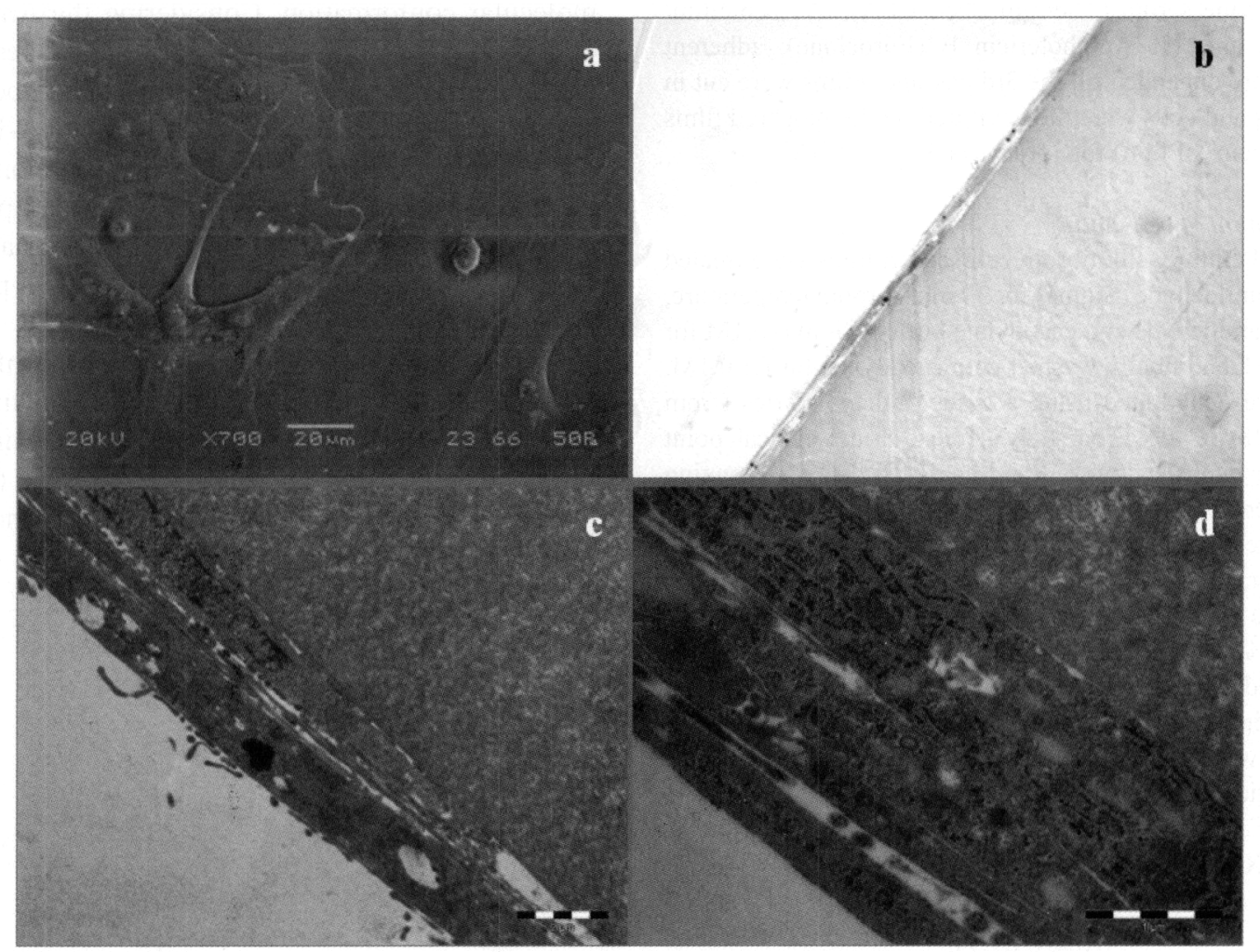

Fig. 2. Adipose-derived stem cells cultured on R fibroin film: a) SEM image; b) light microscopy microphotograph of a film transversal section showing the cell layer, Toluidine Blue Staining, magnification 20x; c) and d) TEM images of a film transversal section showing the cell attachment organized in multilayer, bar in c): $2 \mu \mathrm{m}$; bar in d): $1 \mu \mathrm{m}$.

conformations, index of a conformational transition in place (Table 1).

The results of DSC analysis were reported in Figure 1: increasing pectin concentration, the endothermic event of fibrin degradation shifted to higher temperatures (from $285^{\circ} \mathrm{C}$ for B film to $292^{\circ} \mathrm{C}$ for $\mathrm{D}$ film) and the exothermic event of fibroin crystallization $\left(215^{\circ} \mathrm{C}\right)$ vanished; moreover, increasing pectin concentration, an exothermic event occured at $242^{\circ} \mathrm{C}$. Adding glycerol, an endothermic peak compared at $235-240^{\circ} \mathrm{C}$ and this phenomenon was even more evident in the case of films composed by pectin:glycerol in ratio 1:2.

To evaluate the influence of different composition on film sterilization and cell attachment, R (fibroin $82 \%$, pectin $6 \%$, glycerol $12 \% \mathrm{w} / \mathrm{w}$ ) and $\mathrm{T}$ (fibroin $70 \%$, pectin $10 \%$, glycerol $20 \%$ ) films were selected for further analysis. $\mathrm{R}$ and $\mathrm{T}$ films were sterilized by moist heat, dry heat and gamma irradiation. Dry heat sterilization was not applicable for silk fibroin because films appeared hard, dry and yellowish (data not shown), while the other two methods of sterilization could be exploited. All films stand the sterility test by BacT/ALERT 3D system (data not shown). Moreover, the sterilization, both steam sterilization and gamma rays, did not induce fibroin degradation because the same peaks were appreciated by FTIR analysis $\left(\sim 1622 \mathrm{~cm}^{-1}\right.$ after steam sterilization, $\sim 1623 \mathrm{~cm}^{-1}$ after $20 \mathrm{kGy}$ sterilization and $\sim 1624 \mathrm{~cm}^{-1}$ after $60 \mathrm{kGy}$ sterilization). However, after gamma radiation a less energy was requested for fibroin degradation: in fact, the DSC analysis shows the endothermic peak at $\sim 288^{\circ} \mathrm{C}$ after steam steriliazation, $\sim 287^{\circ} \mathrm{C}$ after $20 \mathrm{kGy}$ sterilization and $\sim 288^{\circ} \mathrm{C}$ after $60 \mathrm{kGy}$ sterilization, but the energy was higher after autoclave sterilization than after irradiation with both of the doses.

The results of cell culture on silk fibroin films were reported in Figure 2. Silk fibroin films maintained their structural integrity until the end of cell culture. The morphological investigations showed that cells adhered to the support, with a fibroblast-like shape and reached confluence (Figure 2a). Adhesion of cells occurred without film penetration, since it did not show porosity. Toluidine Blue staining indicated that cells adhered to 
both $\mathrm{R}$ and $\mathrm{T}$ films, but the best adhesion was observed using $\mathrm{R}$ film (Figure 2b). The ultrastructural analysis on $R$ film suggested the presence of adhesion molecules that promoted cell anchorage to the film, forming a multilayered cell structure (Figure 2c); moreover, typical active-cell features as nuclei, mitochondria, rough endoplasmic reticulum, lysosomes and vacuoles were observed (Figures $2 \mathrm{c}$ and $2 \mathrm{~d}$ ).

\section{DISCUSSION}

Silk fibroin films were thecnological characterized and, according to FTIR and DSC analysis, a stable fibroin conformation was obtained using pectin in concentration of $6 \% \mathrm{w} / \mathrm{w}$. Up to this pectin concentration, silk fibroin conformation is unchanged: probably, a maximum number of sites for pectin-fibroin interaction is saturated at $6 \%$ pectin concentration. The best results, in terms of elasticity and resistance, were obtained in presence of glycerol in order to reach a pectin/glycerol ratio of 1:2. Moreover, the DSC analysis has shown an exothermic event at $\sim 240^{\circ} \mathrm{C}$ associated to pectin degradation and connected to the formation of new links, such as crosslinking or cyclization $(37,38)$. After adding glycerol, an endothermic peak appeared at $\sim 240^{\circ} \mathrm{C}$ : this peak is similar to that of pectin degradation, but of opposite nature, and it is probably due to the molecular interation between pectin and glycerol; in fact, this pectin-glycerol interaction phenomenon is even more evident in the case of films composed by pectin:glycerol in ratio $1: 2$.

The steam sterilization process can be useful for silk fibroin films: several authors have applied moist heat sterilization whithout any appreciable fibroin alteration $(16,17,39-41)$. On the other side, Lawrence et al. (25) observed that the sterilization with autoclave increased Silk II structure because hydrostatic pressure increases elastic modulus and then crystalline structure content; saturated vapor environment decreases the $\mathrm{Tg}$ of silk fibroin, that combined with high temperature increases fibroin chain movement. Moreover, our results indicate that after gamma radiation a less energy was requested for fibroin degradation, probably due to a peptide bond weakening. Kojthung et al. (42) evaluated that gamma radiation reduces silk fibroin tensile strength, molecular weight, and $\beta$-sheet content: this effect is more pronounced by increasing radiation intensity. On the other side, George et al. (43) observed that gamma radiation is the most suitable method for the sterilization of silk fibroin films for corneal tissue engineering.

Finally, the presence of pectin could enhance the cell adhesion because it mimics the polysaccharide structure of the extracellular matrix. In fact, pectin improves osteoblasts adhesion and proliferation on porous poly- lactic-co-glycolic acid matrix (44), promotes murine fibroblast and human muscle cell growth (45), improves the biocompatibility of medical devices $(46,47)$. Munarin et al. (48) obtained an injectable vehicle composed by pectin microspheres suitable for bone tissue regeneration. On the other hand, Lu et al. (34) observed that the glycerol concentration of $30 \% \mathrm{w} / \mathrm{w}$ was necessary to obtain adequate silk fibroin films for fibroblast cell culture. Our results indicate that the concentration of $12 \% \mathrm{w} / \mathrm{w}$ guarantees the adipose-derived stem cell adhesion.

In conclusion, the fibroin casting method with pectin and glycerol confers stability to fibroin structure and elasticity to the films. For these reasons, fibroin films are promising supports for ADSCs culture as feeder layer during the production of bioengineered skin. This construct could be advantageously employed in cutaneous wound healing or where the use of ADSCs scaffold is indicated in both human and veterinary field.

\section{ACKNOWLEDGEMENTS}

This work was supported by Pavia and Milan Universities, and Eurostars project E!5227 FIBROSPHERE. The authors thank Gammatom S.r.l. (Guanzate, Italy) for gamma sterilization and Dr Vittorio Necchi (Centro Grandi Strumenti, Pavia University) for the ultrastructural investigation.

\section{REFERENCES}

1. Rheinwald JG, Green H. Serial cultivation of strains of human epidermal keratinocytes: the formation of keratinizing colonies from single cells. Cell 1975; 6:33144.

2. Suzuki K. Multistep nature of X-ray-induced neoplastic transformation in mammalian cells: genetic alterations and instability. J Radiat Res 1997; 38:55-63.

3. Martin MJ, Muotri A, Gage F, Varki A. Human embryonic stem cells express an immunogenic nonhuman sialic acid. Nat Med 2005; 11:228-32.

4. Stacey GN, Cobo F, Nieto A, Talavera P, Healy L, Concha A. The development of 'feeder' cells for the preparation of clinical grade hES cell lines: challenges and solutions. $\mathbf{J}$ Biotechnol 2006; 125:583-8.

5. Takeuchi T, Wang L, Mori S, Nakagawa K, Yoshikura H, Kanda T. Characterization of mouse 3T3-swiss albino cells available in Japan: necessity of quality control when used as feeders. Jpn J Infect Dis 2008; 61:9-12.

6. Sugiyama H, Maeda K, Yamato M, Hayashi R, Soma T, Hayashida Y, Yang J, Shirakabe M, Matsuyama A, Kikuchi A, Sawa Y, Okano T, Tano Y, Nishida K. Human adipose 
tissue-derived mesenchymal stem cells as a novel feeder layer for epithelial cells. J Tissue Eng Regen M 2008; 2:445-9.

7. Ebrahimian TG, Pouzoulet F, Squiban C, Buard V, André M, Cousin B, Gourmelon P, Benderitter M, Casteilla L, Tamarat R. Cell therapy based on adipose tissue-derived stromal cells promotes physiological and pathological wound healing. Arterioscler Thromb Vasc Biol 2009; 29:503-10.

8. Mizuno H, Nambu M. Adipose-derived stem cells for skin regeneration. Methods Mol Biol 2011; 702:453-9.

9. Altman AM, Matthias N, Yan Y, Song YH, Bai X, Chiu ES, Slakey DP, Alt EU. Dermal matrix as a carrier for in vivo delivery of human adipose-derived stem cells. Biomaterials 2008; 29:1431-42.

10. Zhong SP, Zhang YZ, Lim CT. Tissue scaffolds for skin wound healing and dermal reconstruction. Wiley Interdiscip Rev Nanomed Nanobiotechnol 2010; 2:510-25.

11. Meinel L, Hofmann S, Karageorgiou V, Kirker-Head C, McCool J, Gronowicz G, Zichner L, Langer R, VunjakNovakovic G, Kaplan DL. The inflammatory responses to silk films in vitro and in vivo. Biomaterials 2005; 26:147-55.

12. Cao $\mathrm{Y}$, Wang B. Biodegradation of silk biomaterials. Int $\mathrm{J}$ Mol Sci 2009; 10:1514-24.

13. Vepari C, Kaplan DL. Silk as a biomaterial. Prog Polym Sci 2007; 32:991-1007.

14. Altman GH, Diaz F, Jakuba C, Calabro T, Horan RL, Chen J, Lu H, Richmond J, Kaplan DL. Silk-based biomaterials. Biomaterials 2003; 24:401-16.

15. Altman GH, Horan RL, Lu HH, Moreau J, Martin I, Richmond JC, Kaplan DL. Silk matrix for tissue engineered anterior cruciate ligaments. Biomaterials 2002; 23:413141.

16. Meinel L, Hofmann S, Karageorgiou V, Zichner L, Langer R, Kaplan D, Vunjak-Novakovic G. Engineering cartilagelike tissue using human mesenchymal stem cells and silk protein scaffolds. Biotechnol Bioeng 2004; 88:379-91.

17. Wang Y, Blasioli DJ, Kim HJ, Kim HS, Kaplan DL. Cartilage tissue engineering with silk scaffolds and human articular chondrocytes. Biomaterials 2006; 27:4434-42.

18. Dal Pra I, Chiarini A, Boschi A, Freddi G, Armato U. Novel dermo-epidermal equivalents on silk fibroin-based formic acid-crosslinked three-dimensional nonwoven devices with prospective applications in human tissue engineering/ regeneration/repair. Int J Mol Med 2006; 18:241-7.

19. Wang X, Klugea JA, Leiskb GG, Kaplan DL. Sonicationinduced gelation of silk fibroin for cell encapsulation. Biomaterials 2008; 29:1054-64.

20. Sobajo C, Behzad F, Yuan XF, Bayat A. Silk: a potential medium for tissue engineering. Eplasty 2008; 8:e47.

21. Altman AM, Yan Y, Matthias N, Bai X, Rios C, Mathur AB, Song YH, Alt EU. IFATS collection: human adiposederived stem cells seeded on a silk fibroin-chitosan scaffold enhance wound repair in a murine soft tissue injury model. Stem Cells 2009; 27:250-8.

22. Altman AM, Gupta V, Ríos CN, Alt EU, Mathur AB. Adhesion, migration and mechanics of human adiposetissue-derived stem cells on silk fibroin-chitosan matrix. Acta Biomater 2010; 6:1388-97.

23. Guan G, Bai L, Zuo B, Li M, Wu Z, Li Y, Wang L. Promoted dermis healing from full-thickness skin defect by porous silk fibroin scaffolds (PSFSs). Biomed Mater Eng 2010; 20:295-308.

24. Chen X, Shao Z, Marinkovic NS, Miller LM, Zhou $\mathrm{P}$, Chance MR. Conformation transition kinetics of regenerated Bombyx mori silk fibroin membrane monitored by time-resolved FTIR spectroscopy. Biophys Chem 2001; 89:25-34.

25. Lawrence BD, Omenetto F, Chui K, Kaplan DL. Processing methods to control silk fibroin film biomaterial features. $\mathrm{J}$ Mater Sci 2008; 43:6967-85.

26. Sugihara A, Sugiura K, Morita H, Ninagawa T, Tubouchi $\mathrm{K}$, Tobe R, Izumiya $\mathrm{M}$, Horio $\mathrm{T}$, Abraham NG, Ikehara S. Promotive effects of a silk film on epidermal recovery from full-thickness skin wounds. Proc Soc Exp Biol Med 2000; 225:58-64.

27. Zhang X, Reagan MR, Kaplan DL. Electrospun silk biomaterial scaffolds for regenerative medicine. Adv Drug Deliver Rev 2009; 61:988-1006.

28. Mandal BB, Park S-H, Gil ES, Kaplan DL. Multilayered silk scaffolds for meniscus tissue engineering. Biomaterials 2011 ; 32:639-51.

29. Um IC, Kweon HY, Park YH, Hudson S. Structural characteristics and properties of the regenerated silk fibroin prepared from formic acid. Int $\mathbf{J}$ Biol Macromol $2001 ; 29: 91-7$.

30. Lv Q, Cao C, Zhang Y, Man X, Zhu H. The preparation of insoluble fibroin films induced by degummed fibroin or fibroin microspheres. J Mater Sci Mater Med 2004; 15:1193-7.

31. Chen X, Shao Z, Knight DP, Vollrath F. Conformation transition kinetics of Bombyx mori silk protein. Proteins 2007; 68:223-31.

32. Faragò S, Torre M.L. Film of fibroin and pectin, in particular for medical applications and use in tissue engineering, and preparation method thereof IT2010MI2010A002081.

33. Lu S, Wang X, Lu Q, Zhang X, Kluge JA, Uppal N, Omenetto F, Kaplan DL. Insoluble and flexible silk films 
containing glycerol. Biomacromolecules 2010; 11:143-50.

34. Munarin F, Tanzi MC, Petrini P. Advances in biomedical applications of pectin gels. Int J Biol Macromol 2012; 51: 681-9.

35. Chlapanidas T, Faragò $S$, Mingotto $F$, Crovato F, Tosca MC, Antonioli B, Bucco M, Lucconi G, Scalise A, Vigo D, Faustini M, Marazzi M, Torre ML. Regenerated silk fibroin scaffold and infrapatellar adipose stromal vascular fraction as feeder layer: a new product for cartilage advanced therapy. Tissue Eng Part A 2011; 17:1725-33.

36. Faustini M, Bucco M, Chlapanidas T, Lucconi G, Marazzi M, Tosca MC, Gaetani P, Klinger M, Villani S, Ferretti V, Vigo D, Torre ML. Non expanded mesenchymal stem cells for regenerative medicine: yield in stromal vascular fraction from adipose tissues. Tissue Eng Part C 2010; 16:1515-21.

37. Einhorn-Stoll U, Kunzek H, Dongowski G. Thermal analysis of chemically and mechanically modified pectins. Food Hydrocolloid 2007; 21:1101-12.

38. Einhorn-Stoll U, Kunzek H. Thermoanalytical characterisation of processing-dependent structural changes and state transitions of citrus pectin. Food Hydrocolloid 2009; 23:40-52.

39. Hofmann S, Hagenmuller H, Koch AM, Muller R, VunjakNovakovic G, Kaplan DL, Merkle HP, Meinel L. Control of in vitro tissue-engineered bone-like structures using human mesenchymal stem cells and porous silk scaffolds. Biomaterials 2007; 28:1152-62.

40. Von Rechenberg B, Uebersax L, Apfel T, Schubotz R, Hilbe M, Meinel L, Kim HJ, Kaplan DL, Merkle HP, Auer JA. Silk fibroin as an adaptable 3-D scaffold for defect repair in subchondral bone. Eur Cells Mater 2007; 13:15-6.

41. MacIntosh AC, Kearns VR, Crawford A, Hatton PV. Skeletal tissue engineering using silk biomaterials. J Tissue Eng Regen Med 2008; 2:71-80.

42. Kojthung A, Meesilpa P, Sudatis B, Treeratanapiboon L,
Udomsangpetch R, Oonkhanond B. Effects of gamma radiation on biodegradation of Bombyx mori silk fibroin. Int Biodeter Biodegr 2008; 62:487-90.

43. George KA, Shadforth AMA, Chirila TV, Laurent MJ, Stephenson S-A, Edwards GA, Madden PW, Hutmacher DW, Harkin DG. Effect of the sterilization method on the properties of Bombyx mori silk fibroin film. Mater Sci Eng C Mater Biol Appl 2012; http://dx.doi.org/10.1016/j. msec.2012.10.016.

44. Liu TL, Miao JC, Sheng WH, Xie YF, Huang Q, Shan YB, Yang JC. Cytocompatibility of regenerated silk fibroin film: a medical biomaterial applicable to wound healing. $\mathrm{J}$ Zhejiang Univ Sci B 2010; 11:10-6.

45. Morra M, Cassinelli C, Cascardo G, Nagel MD, Della Volpe C, Siboni S, Maniglio D, Brugnara M, Ceccone G, Schols HA, Ulvskov P. Effects on interfacial properties and cell adhesion of surface modification by pectic hairy regions. Biomacromolecules 2004; 5:2094-104.

46. Bussy C, Verhoef R, Haeger A, Morra M, Duval JL, Vigneron P, Bensoussan A, Velzenberger E, Cascardo G, Cassinelli C, Schols H, Knox JP, Nagel MD. Modulating in vitro bone cell and macrophage behavior by immobilized enzymatically tailored pectins. J Biomed Mater Res A 2008; 86:597-606.

47. Nagel MD, Verhoef R, Schols H, Morra M, Knox JP, Ceccone G, Della Volpe C, Vigneron P, Bussy C, Gallet M, Velzenberger E, Vayssade M, Cascardo G, Cassinelli C, Haeger A, Gilliland D, Liakos I, Rodriguez-Valverde M, Siboni S. Enzymatically-tailored pectins differentially influence the morphology, adhesion, cell cycle progression and survival of fibroblasts. Biochim Biophys Acta 2008; 1780:995-1003.

48. Munarin F, Guerreiro SG, Grellier MA, Tanzi MC, Barbosa MA, Petrini P, Granja PL. Pectin-based injectable biomaterials for bone tissue engineering. Biomacromolecules 2011; 12:568-77. 